\title{
Morphology of the eggs of the genus Belminus (Hemiptera: Reduviidae: Triatominae) by optical and scanning electron microscopy
}

\author{
CLAUDIA M. SANDOVAL ${ }^{1}$, ELSA NIEVES ${ }^{1}$, VÍCTOR M. ANGULO ${ }^{2}$, \\ JOÃO ARISTEU DA ROSA ${ }^{3} \&$ ELIS ALDANA ${ }^{4,5}$ \\ ${ }^{1}$ Laboratorio de Parasitología Experimental (LAPEX). Facultad de Ciencias. Universidad de Los Andes, Mérida, República Bolivari- \\ ana de Venezuela. E-mail: magaly6@yahoo.com,nevelsa@ula.ve \\ ${ }^{2}$ Centro de Investigaciones en Enfermedades Tropicales CINTROP-UIS, Universidad Industrial de Santander, Piedecuesta, Santander, \\ Colombia. E-mail: cintrop@ hotmail.com \\ ${ }^{3}$ Faculdade de Ciências Farmacêuticas/UNESP/Araraquara, Sao Paulo, Brazil. E-mail: rosaja@fcfar.unesp.br \\ ${ }^{4}$ Laboratorio de Entomología "Herman Lent". Facultad de Ciencias. Universidad de Los Andes, Mérida, República Bolivariana de \\ Venezuela.E-mail: aldana@ula.ve. \\ ${ }^{5}$ Corresponding author: Email. aldana@ula.ve
}

\begin{abstract}
The external morphology of eggs of the species Belminus corredori Galvão \& Angulo, 2006, Belminus herreri Lent \& Wygodzinsky, 1979 and Belminus ferroae Sandoval, Pabón, Jurberg \& Galvão, 2007 is described for the first time using scanning electron microscopy (SEM). Females lay one egg at a time; the shape of the egg is oval with lateral flattening, a rounded caudal area and a true and simple convex operculum. The average size of the egg among these species is $0.51-$ $0.58 \mathrm{~mm}$ in length and $0.36-0.4 \mathrm{~mm}$ in width. As a generic character we highlight the discovery of a chorion rim with one to four grooves always joined to the micropyles. All species present a clear polygonal pattern only in the operculum and in the egg's cephalic region, while the median and caudal regions show a smooth appearance, features that are shared only with the eggs of the genus Alberprosenia. A discriminant analysis of the polygonal design of the operculum proved to be useful for the identification of the species.
\end{abstract}

Key words: chorion sculpturing, polygonal cells, operculum, eggshell, SEM

\section{Introduction}

The ultrastructure of the chorion of insect eggs is related to morphological, physiological and taxonomic properties (Hinton 1981; Suludere et al. 1999; Candan 1999). In Heteroptera, including the Triatominae Jeannel, 1919, studies of the egg stage have enabled the identification of characters important for determining classification and phylogenetic relationships (Barata 1981; Obara et al. 2007a; González et al. 2009; Matesco et al. 2009). There are 141 species of Triatominae (Schofield \& Galvão, 2009; Jurberg et al. 2009), some of which are regarded as important vectors of Trypanosoma cruzi (Chagas, 1909), the etiologic agent of Chagas disease. Pinto (1924) and Galliard (1935) were pioneers in addressing the external morphology of eggs in this subfamily. The former described the external morphology of the egg of Triatoma brasiliensis Neiva, 1911 and the latter showed that the architecture of the exchorion in Triatominae is useful in distinguishing among species. These studies have led to many documents addressing the description of the macroscopic and microscopic aspects of numerous triatomine species (Abalos \& Wygodzinsky 1951; Barth \& Muth 1958; Foratinni \& Barata 1974; Lent \& Wygodzinsky 1979). Barata (1981), Costa et al. 1991 and Jurberg et al. (1993) defined the characteristics for the genera Rhodnius Stål, 1859, Cavernicola Barber, 1937 and Dipetalogaster Usinger, 1939. Barata (1998) extended this analysis by describing and defining egg traits of taxonomic value in the genera Alberprosenia Martínez \& Carcavallo, 1977, Cavernicola, Dipetalogaster, Eratyrus Stål, 1859, Microtriatoma Prosen \& Martínez, 1952, Panstrongylus Berg, 1879, Psammolestes Bergroth, 1911, Rhodnius and Triatoma Laporte, 1832. More recently, studies have been motivated by the 